\title{
CLINICAL ANATOMY OF URETHERIC CONSTRAINTS: A SYSTEMATIC REVIEW
}

\section{André Pontes Gonçalves', Mariana Schimming de Lima², Ana Luiza Nogueira Silveira ${ }^{3}$, Marina Martins Sobreira ${ }^{3}$, Isabela Harumi Gomi ${ }^{2}$, Pedro Henrique Sales Almeida ${ }^{2}$, Thays AKemi Nogueira Tamaributi2 ${ }^{2}$ Idiberto José Zotarelli Filho ${ }^{4,5,7^{*}}$ and Rogério Rodrigo Ramos ${ }^{6}$}

${ }^{1}$ Medical student at the University of Contestado, Mafra, SC, Brazil

2Medical Students at the University of Brazil (UB), Fernandópolis, SP, Brazil

${ }^{3}$ Medical students of the University of Marília, Marília, SP, Brazil

${ }^{4}$ Doctor of the Zotarelli-Filho Scientific Work, São José do Rio Preto/SP, Brazil

${ }^{5}$ Bentham Science Ambassador, Brazil

${ }^{6}$ Doctor of the Universidade Brasil, Medicine Course, Fernandópolis, SP, Brazil

${ }^{7}$ Faceres - Medical School of São José do Rio Preto, SP, Brazil

\section{ARTICLE INFO}

Article History:

Received $19^{\text {th }}$ February, 2020

Received in revised form

$20^{\text {th }}$ March, 2020

Accepted $28^{\text {th }}$ April, 2020

Published online $30^{\text {th }}$ May, 2020

Key Words:

Calculus ureters, Constriction,

Anatomy.

*Corresponding author:

Idiberto José Zotarelli Filho

\begin{abstract}
Introduction: The ureter is a channel responsible for carrying urine to the urinary bladder, through peristalsis and contractions, however, this channel can be affected by three types of constrictions, at the junction of the ureter with the renal pelvis called the ureteropelvic, from the edge of the pelvis to the passage of the iliac blood vessels called the abdominopelvic and at the intersection of the external iliac artery and the bladder wall called the vesicoureteral. These points, then, are relevant for clinical analysis, since they are the cause of several pathologies such as urinary incontinence, intrinsic urinary sphincter dysfunction, and obstruction by kidney stones. Objective: This study aims to carry out a systematic review study of the three points of ureteral contractions. Methodology: The present proposed literature review on the anatomical points of ureteric constrictions, carried out between August and September 2018. Result: It was found that the most widely used medications for pain relief are antispasmodics, non-opioid analgesics, nonsteroidal anti-inflammatory drugs (NSAIDs) and narcotics. Conclusion: It is concluded that, for a better diagnosis, tests such as uroflowmetry, voiding urethrocystography, cystoscopy, and ultrasound are used.
\end{abstract}

Copyright (C) 2020, André Pontes Gonçalves et al. This is an open access article distributed under the Creative Commons Attribution License, which permits unrestricted use, distribution, and reproduction in any medium, provided the original work is properly cited.

Citation: André Pontes Gonçalves, Mariana Schimming de Lima, Ana Luiza Nogueira Silveira Marina Martins Sobreira et al. "Clinical anatomy of uretheric constraints: a systematic review”, International Journal of Development Research, 10, (05), 35934-35936.

\section{INTRODUCTION}

Constriction can be caused by several pathologies, such as kidney stones, urinary tract infections, congenital stenosis, cancer, STIs (Sexually Transmitted Infections), trauma or urethral injuries. Symptoms of constriction are reduced urine flow, voiding difficulty, spacing, urinary incontinence, nocturia and burning during urination (McDougal, 2018). The complications when having a urethral narrowing are that the bladder muscle becomes overloaded, having to make a greater effort to generate urinary flow in order to overcome the region of stenosis. Part of the urine can get trapped inside and result in urinary infections (Ximenes, 2010). The exams to evaluate the urinary tract and detect urethral constriction are intravenous urography, imaging exams such as tomography and excretory urography (Leão, 2002). The treatment for ureteral constriction can be prophylactic antibiotic therapy, pyeloplasty, which is the dissection of the proximal ureter and pelves, for the reconstruction of urinary drainage and ureteral dilation with a balloon to increase the internal diameter of the urethral canal (Hachul, 2004). Based on the text presented, the study aimed to conduct a systematic review study of the three points of ureteral constriction.

\section{METHODOLOGY}

The type of work was based on a literature review on the points of ureteric constriction. A cadaveric specimen from the 
human anatomy laboratory of the University of Brazil was used as a reference to demonstrate the points of ureteral contractions (Figure 1A, B, C, and D). The data were obtained from trusted sites, such as Scielo, Pubmed, Lilacs, and the University library. The study was carried out from August 2018 to November 2019, summarizing and transcribing information relevant to the work. To facilitate the study, the systematic review was divided into three subtitles such as the location of the ureteric constrictions; causes, signs, and symptoms of constrictions and; diagnoses and treatments. addition, bladder and prostate carcinomas invading the ureters in their intravesical segment may also be responsible for the obstruction. These congenital or acquired obstructive pathologies lead to bilateral renal impairment, with the establishment of uremia and renal failure with damage to the parenchyma. It should also be remembered that, as a cause of constriction, the traumatic stricture of the urethra and inflammatory fibrosis of the same organ (Joel, 2004). Usually, the signs and symptoms are severe pain in the lower back, renal colic, difficulty and pain in urination.

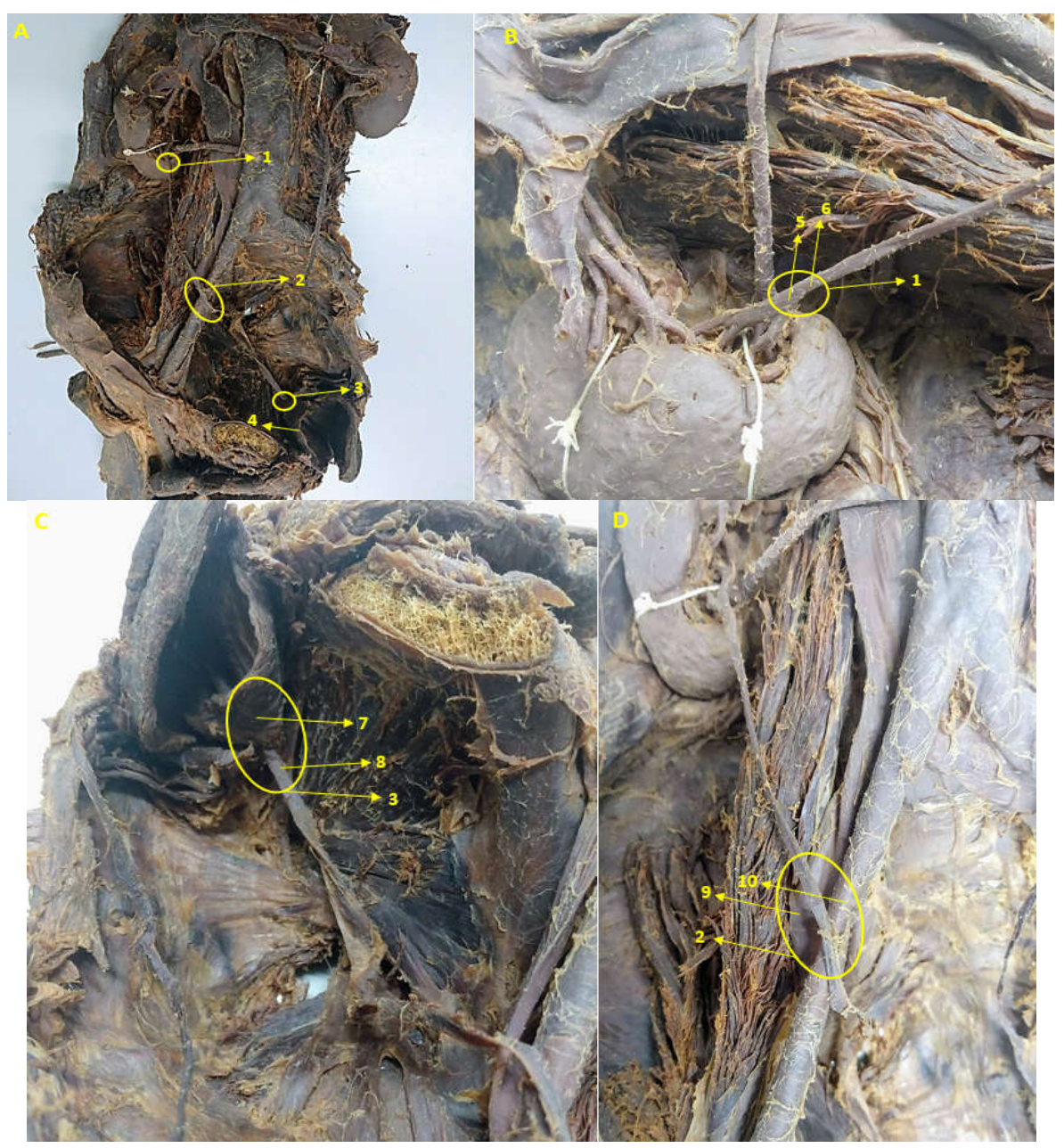

Figure 1. Points of ureteric constriction, being (1) ureteropelvic; (2) abdominopelvic; (3) intramural; and joining structures to form constrictions, being (4) urinary bladder; (5) renal pelvis; (6) ureter abdominal part; (7) detrusor muscle of the bladder; (8) ureter pelvic part; (9) external iliac vein and (10) external iliac artery

\section{DEVELOPMENT}

Location of ureteric constrictions: The processes of ureteral constriction in their final evolution lead to ureteral obstructions, which are the reasons for this literary review. Ureteric constrictions have three types, the first being ureteropelvic (Figures 1A and B) or known as pyeloureteral located by the junction of the renal pelvis with the ureter, the second abdominopelvic (Figures $2 \mathrm{~A}$ and $\mathrm{C}$ ) located at the intersection of the iliac vessels and the third type called vesicureteral or intramural (Figures 3A and D), located at the junction of the ureter with the muscle wall of the urinary vesicle (Leão, 2002; Filho, 2006).

Causes, signs, and symptoms of constrictions: The main causes of ureteral constrictions are kidney stones and tumor invasion, followed by congenital changes (Brin, 1975). In
The pain is mainly caused by distension, stretching, and spasm, secondary to acute ureteral obstruction. Because they are very clear symptoms of problems in the urinary tract, sometimes a detailed and well-made diagnosis ends up being dispensed with (Junior, 1997).

Diagnostics and treatments: It is essential that adequate anamnesis is performed together with laboratory tests to obtain an accurate diagnosis (Porena, 2007). From that, a helical computed tomography of the abdomen and pelvis is requested. In about $10 \%$ of cases, the suspected diagnosis of ureterolithiasisis ruled out at the expense of another diagnosis such as adnexal masses, pyelonephritis, colonic disease, appendicitis, pelvic lymphadenopathy (Katz, 2000). Another exam, more accessible, is abdominal radiography, but it is not advisable to carry out the diagnosis without complementary exams since it does not distinguish between pelvic calcification and phlebolites. Urocultureshould be performed 
in some situations, such as symptoms of urinary tract infection, severe leukocyturia, bacteriuria, positive nitrite test or according to calculation characteristics (Joel, 2004). Given the diagnosis, the most widely used medications for pain relief are antispasmodics, non-opioid analgesics, non-steroidal antiinflammatory drugs (NSAIDs) and narcotics. At the time of ureteral lithiasis, treatment can be conservative or interventional (Preminger, 2009). The urgent intervention is indicated in a patient with upper urinary tract infection associated with obstruction, deterioration of renal function, intractable pain or vomiting, anuria or obstruction in a single kidney or transplanted kidney. Conservative treatment, on the other hand, should be indicated in small calculations, if it is the patient's option, and when the chance of spontaneous elimination is favorable and/or can be accelerated by drugs (Sowter, 2006). Complications can occur both during conservative and interventional treatment, although they are uncommon. Complications include infection, "stone street" (steinstrasse), ureteral stenosis, renal rupture, ureteral injuries or avulsions. The most frequent clinical cases are urolithiasis, followed by pielo-urethral junction stenosis (JUP) and hydronephrosis. All have symptoms of obstruction, loss of renal function, development of kidney stones (Muslumanoglu, 2006).

\section{Conclusion}

It is concluded that any type of ureteral obstruction can restrict urinary flow, with progressive loss of renal function. There are no reports of recurrence in the literature of the three cases of ureteral obstructions. Therefore, further anatomical and clinical studies of ureteral obstructions are suggested.

Declaration of potential conflict of interest The authors declare no conflict of interest.

\section{REFERENCES}

Brin EN, Schiff M Jr, Weiss RM. 1975. Palliative urinary diversion for pelvic malignancy. Journal Urology. v.113, n.5, p.619-22.
Filho EOF, Leão ARS, Capobianco J. 2006. Definição do nível da junção ureterovesical pela tomografia computadorizada. Revista de Radiologia Brasileira. v.39, n.6.

Hachul M, Ikari O, Leslie B. et al., 2014. Estenose da Junção Pieloureteral. Revista Faculdade de Ciências Médicas de Sorocaba. v.16, n.3, p155-156.

Joel MH, Teichman MD. 2004. Acute renal colic from ureteral calculus. New England Journal Medicine. v.350, p.684693.

Junior NRN,Srougi M, Lemos GC. Fisiopatologia da obstrução urinária. Revista de Medicina da USP. 1997, p.25-30.

Katz DS., Scheer M., Lumerman JH. et al., 2000. Alternative or additional diagnoses on unenhanced helical computed tomography for suspected renal colic: experience with 1000 consecutive examinations. Department of Radioly and Urology. Winthrop University Hospital., v.56, p.53-7.

Leão RIC. 2002. Urografia intravenosa: técnica e interpretação. Colégio Brasileiro de Radiologia Brasileira e Diagnóstico por Imagem. v.35, n.4, p.799-824.

McDougal WS., Wein AJ., Kavoussi LR. et al. 2018. Campbell-Walsh Urologia: Perguntas e respostas da décima primeira edição. Brasil: Elsevier.

Muslumanoglu AY, Tefekli A, Karadag MA. 2006. Impact of percutancousacess point number and location on complication and success rates in percutancousnephrolithotomy. Department of Urology, Haseki Teaching and Research Hospital., v.77, p.340-6.

Porena M, Guiggi P, Micheli C. Prevention of stone disease. Department of Urology. University of Perugia. Italy, 2007, v.79, n.1, p.37-46.

Preminger GM., Tiselius HG., Assimos DG. et al. 2009. Guideline for the management of ureteral calculi. Library Medicine Urology. v.22, n.2, p.160-164.

Sowter SJ, Tolley DA. The management of ureteric colic. Library of Medicine. 2006, v.16, n.2, p.71-76.

Ximenes, S.F. 2010. Urologia Fundamental: Reconstrução Urugenital. Sociedade Brasileira de Urologia. v.3, n.3, p.319-326. 